\title{
An assessment of the trainability of beggars and the destitute in Abakaliki Nigeria: implication for policy on their health, vocational rehabilitation and social reintegration
}

\author{
Tina Nweze ${ }^{1,2}$, Asfa M Yasin²,3, Ugochukwu C Okolie ${ }^{2,4}$, Alexander G Ogundele ${ }^{2,5}$, \\ Chigozie J Uneke ${ }^{2,6}$, Uzoma Agwu ${ }^{2,7}$, Philip C Omoke ${ }^{2,8}$, Nnenna Ajayi ${ }^{2,9}$
}

1. Department of Educational Foundation, Ebonyi State University Abakaliki Nigeria.

2. PATH-BESTInterdisciplinary Research Group, Ebonyi State University Abakaliki Nigeria.

3. PSS Central Institute of Vocational Education, Bhopal, India.

4. Department of Technical \& Vocational Education, Ebonyi State University Abakaliki Nigeria.

5. School of Technical Education, Kwara State College of Education (Technical), Lafiagi Nigeria.

6. African Institute for Health policy \& Health Systems, Ebonyi State University Abakaliki Nigeria.

7. Department of Obstetrics \& Gynecology, Ebonyi State University Abakaliki Nigeria.

8. Department of Economics, Federal University Alike Ikwo, Nigeria.

9. Department of Internal Medicine, Ebonyi State University Abakaliki Nigeria.

\begin{abstract}
Background: Begging and destitution constitute serious health and social problems in low and middle-income countries (LMICs).

Objectives: The objective of this study was to assess the trainability of beggars and the destitute in Abakaliki Nigeria in order to provide scientific evidence required for the development of a policy on their health, vocational rehabilitation and social reintegration.
\end{abstract}

Methods: The study was a cross-sectional descriptive survey of 50 purposively selected beggars and destitute persons identified from motor parks, church cathedrals, market places etc. Data was collected using a structured interviewer-administered questionnaire. Analysis was based on mean rating (MNR), median rating (MDR), and range. Interview of each respondent lasted approximately 20 minutes.

Results: Of the 50 respondents who participated in this study, 17 (34\%) were females. Most subjects were of age category $31-$ 35 years (30\%) and 36-40 years (34\%). Fifteen (30\%) admitted having sight impairment while $17(34 \%)$ admitted that they were physically challenged. The outcome of the trainability assessment showed relatively high mean ratings (MNRs) ranging from 3.42-4.06 on a scale of 5 points.

Conclusion: The findings of this study clearly suggest that there is a very high potential for the vocational rehabilitation and social reintegration of beggars and the destitute in the study area.

Keywords: Beggars, destitute, policy, health, vocational, rehabilitation, reintegration, Nigeria.

DOI: https://dx.doi.org/10.4314/ahs.v19i3.48

Cite as: Nweze T, Yasin AM, Okolie UC, Ogundele AG, Uneke CJ, Agwu U, Omoke PC, Ajayi N. An assessment of the trainability of beggars and the destitute in Abakaliki Nigeria: implication for policy on their health, vocational rehabilitation and social reintegration. Afri Health Sci. 2019;19(3): 2728-2736. https:/ / dx.doi.org/10.4314/ahs.v19i3.48

\section{Corresponding author: \\ Tina Nweze, \\ Department of Educational Foundation, \\ Ebonyi State University Abakaliki Nigeria \\ Tel: +2348037407471 \\ Email: drtyna@yahoo.com}

\section{Introduction}

Begging could be defined as a practice of imploring people to grant one a favour (in the form of gift) which could be money, food, clothes etc without reciprocation or refund ${ }^{1}$. Begging has also been described as an act where some young children are co-opted into leading blind, older people clutching onto long canes and going from ve-

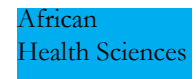

(C) 2019 Nweze et al. Licensee African Health Sciences. This is an Open Access article distributed under the terms of the Creative commons Attribution License (https://creativecommons.org/licenses/BY/4.0), which permits unrestricted use, distribution, and reproduction in any medium, provided the original work is properly cited. 
hicles to vehicles, individuals to individuals while chanting the same lines repeatedly as they accost members of the public with alluring songs and soliciting alms ${ }^{2}$. These beggars are usually found in front of big church cathedrals, banks, hotels, inside filling stations, in motor parks, markets and along major streets/roads. Consequent upon the non-availability of any policy on begging, most of them have no homes and as such, they sleep in odd places not quite different from where they beg alms. Perhaps, nothing defines begging more than the distasteful act of badgering randomly on strangers for money, food, shelter or other utilities. Begging constitutes serious health and social problems in low and middle-income countries (LMICs).

Begging in the streets of urban areas is known to be an age-long profession of highly vulnerable, physically or mentally sick and poverty-ridden individuals in the society $^{3}$. It is therefore an indication of abject poverty for the helpless and perhaps health-challenged poor and demonstrates the failure of persons to adjust according to societal settings ${ }^{3}$. Eight categories of beggars have been described (i) Able-bodied adult beggars; (ii) Able-bodied child beggars; (iii) Hereditary beggars; (iv) Sick or diseased beggars; (v) Physically disabled beggars; (vi) Mentally retarded beggars; (vii) Old and incapable beggars; and (viii). Religious mendicants that is, those who beg because they believe that beggary has the sanction of religion ${ }^{5}$.

In Nigeria, as in many other LMICs, there is an unprecedented increase in the number of beggars and the destitute in urban areas ${ }^{2,6}$. Several scholars have suggested that begging and destitution are associated with the LMICs' faulty socioeconomic, weak health systems and historical background. This in turn is characterized by low income earnings, high unemployment rates, explosion in cost of living, high rates of population growth, inappropriate public policies, poor health status, continued rural- urban migration and massive citizens displacements ${ }^{7,8}$. In spite of the fact that street begging constitutes a nuisance to the health, physical and social environment of cities, the continuing reliance on the activity as a means of livelihood amounts to a waste of human resources and impacts negatively on the health of the beggars. It equally becomes a burden on the already overstretched meagre-income earners of the majority of the work force ${ }^{6}$.
As a result of poor economic situation, many people not only resort to begging as a means of survival but have professionalized it like a trade. Consequently, it is no longer a surprise to see men and women with virtually no trace of physical or mental deformity engage in begging? These individuals mix with the aged, the real physically or mentally impaired and sometimes pretenders who take advantage of and deceive unsuspecting members of the public into giving them alms. Beggars and destitute persons usually employ different techniques capable of appealing to human sentiments and arousing sympathy. Those of them who use these tactics usually shower blessings, praise and exaltations on their supposed alms givers. When these accolades fail to elicit positive responses, they resort to relating tales of misery, sickness and ill luck that have befallen them ${ }^{10}$. Other techniques employed by beggars and destitute persons to attract sympathy include exhibiting their wounds, signs and symptoms of their diseases,exhibiting their babies, singing religious songs etc. In rare cases, some beggars and destitute persons may resort to 'forcing' their supposed alms givers by making nuisance out of themselves or displaying undesirable acts until such persons will be forced to respond positively to their requests.

The negative impacts of begging and destitution to the health and socio-economic development in Nigeria are indisputable. For instance, beggars and destitute persons have been known to suffer diverse chronic illnesses that end up not getting the required medical attention for as long as their lives continue to tick like a clock. Beggars equally contend against dehumanizing occurrences of ritual decapitation, rape, rejection, commercialized body parts plundering, hunger, lynching and physical assaults borne out of hatred for their persons ${ }^{1,2}$.

Unfortunately, there is no public policy that regulates begging and destitution. Neither is there any health policy that outlines guidelines for their healthcare, rehabilitation and meaningful re-integration into society. This is a common situation in the LMICs including most African countries. The current global emphasis on health equity demands that the health and social-wellbeing of the vulnerable like the beggars and the destitute be taken into consideration in the policy making process. Among the important strategies to control begging and destitution, is the enhancement of the capacities of the beggars and the 
destitute with vocational skills. According to Vikash ${ }^{11}$, one of the ways of reducing the menace caused by beggars and destitute persons and improving their health is to equip them with necessary vocational skills. This will enable them seek appropriate health care and acquire self-reliant skills needed for personal and collective economic advancement.

However, before the deployment of vocational training for the beggars and the destitute, it is important to systematically determine their trainability. The objective of this study was to assess the trainability of beggars and the destitute in Abakaliki Nigeria. The study was designed to provide base line scientific information required for the improvementof the health condition and development of a vocational training intervention programme for beggars and the destitute and contribute to the economic growth of the society.

\section{Methods}

\section{Study area/ Population}

The study area is Abakaliki metropolis, the capital of Ebonyi State in southeast Nigeria. Ebonyi State is made up of thirteen Local Government Areas and is divided into three senatorial zones, namely: Ebonyi Central, Ebonyi North and Ebonyi South. Being the State capital, Abakaliki attracts the influx of people from various parts of Nigeria especially those of the Igbo tribe. Abakaliki has arable land, good for planting yam, rice, cassava, sweet potato, groundnut, palm oil, etc. Mainly civil servants, business men/women, and peasant farmers occupy it. There are lots of mineral resources and some of the inhabitants engage in quarry industry. Abakaliki witnesses a high influx of beggars and the destitute because it is the largest town in the state with high level of economic activities.

The target population for this study comprised of beggars and the destitute in Abakaliki metropolis. They are usually found in front of big church cathedrals, banks, hotels, inside filling stations, inside and near motor parks and markets, and along major streets/roads. Some of them have no homes and as such, they sleep in the motor parks, along the streets, market places, around the churches, etc. Consequent upon the non-availability of any policy on begging and destitution, there is no record of the actual number of beggars and the destitute in Abakaliki metropolis. The study inclusion criteria were: (i). Target respondent must be a beggar and/or the destitute; (ii) Must be residing in Abakaliki or its environs; (iii) Must be at least 20 years old (because they are more likely to be receptive to organized rehabilitation programs); (iv) Must be able and willing to give their informed consent.

The study exclusion criteria were: (i). some potential respondents who met the above criteria but were not in stable physical and psychological conditions were excluded from the study because they might not be able to provide reasonable answers to the research questions. (ii). the mentally retarded/challenged were equally excluded in the study because it might be very difficult to obtain their consent, or retrieve information from them.

The study was a cross-sectional descriptive survey. The instrument for data collection was a structured, interviewer-administered questionnaire, considering that most of the beggars and destitute individuals have little or no formal education.

\section{Study design}

The study is a cross-sectional descriptive survey. The instrument for data collection was a structured, interviewer-administered questionnaire, considering that most of the beggars and destitute individuals have little or no formal education. Trained research assistants were engaged to assist the Research Team in the data collection from the respondents. All six Research Assistants had minimum qualifications of a bachelor's degree and were trained for three days. Use of local language for data collection was a core part of the training they received. The questionnaire was first drafted in English and then eventually translated into the Igbo Language to cater for individual respondents without the competence of the English Language level needed for this research. It was structured in such a way to enable the team to obtain relevant information existing or absent without the instrument itself causing any observed changes in the responses of the study participants. The instrument was designed to collect information on the socio-demographic characteristics (Section A) and information on the trainability of the respondents (Section B). It was patterned on a 5-point Likert scale with options ranging from 1 point (very weak) to 5 points (very strong).

Data collection instrument for the research got its validation by three counselors from the University coun- 
seling unit along with two experts from the Vocational and Technical Education Department of Ebonyi State University, Abakaliki. The reliability of the instrument was ensured through a trial testing procedure at Enugu, another southeastern Nigeria State. The Cronbach alpha was used to determine the reliability. The reliability index of the instrument was 0.82 indicating that the instrument was reliable.

A purposive sampling technique was employed and 50 respondents were targeted. Purposive sampling technique was employed for the exercise since there was no documentary evidence on the actual number of the destitute and beggars in Abakaliki metropolis. In order to cover the variables especially gender, age, marital status, etc,representatives of each category were systematically selected. Ten respondents were selected from each of the following locations: (i) the motor parks, (ii) church cathedrals, (iii) streets, (iv) filling stations, and (v) market places. The interview of each respondent lasted approximately 20 minutes. All the 50 individuals approached, gave their consents and responded to the questionnaire-based interview.

\section{Ethical consideration}

Ethical clearance for this study was obtained from the University Research Ethics Committee (UREC) of Ebonyi State University Abakaliki Nigeria. The approval was based on the agreement that participation in the research was voluntary following informed consent; that participants' anonymity would be maintained; and that every finding would be treated with utmost confidentiality and for the purpose of this research only. These were adhered to in this study.

\section{Analysis of data}

The variables assessed were gender (male and female), age bracket, marital status, highest educational qualifica- tion, are you a trained worker? What type of impairment do you have?

The socio-demographic parameters were expressed in percentages (Table 1). The data collected via the questionnaires were analyzed using the methods developed at McMaster University, Hamilton, Ontario, Canada by Johnson and Lavis ${ }^{12}$. The main parameter measured was participants' perceptions of their trainability to enhance vocational skill. The analysis was based on mean rating (MNR), median rating (MDR), and range. For instance, the figures represent Likert rating scale of $1-5$ points, where 1 point $=$ very weak; 2 points $=$ weak; 3 points $=$ moderate; 4 points $=$ strong; and 5 points $=$ very strong.

The range was recorded as the range of values represented by lowest number chosen from the response scale and the highest (eg, 2-5). The mean was calculated by totaling the numbers chosen from the response scale and dividing by the total number of responses to the question. The median was determined by arranging the values chosen from the response scale in ascending order. In terms of analysis, values ranging from 1.00-3.49 points are considered low, whereas values ranging from $3.50-5.00$ points considered high. This cut-off for low or high trainability criteria used was as described in a previous study ${ }^{13}$.

\section{Results}

The socio-demographic profile of the participants is summarized in Table 1 . Of the 50 respondents who participated in this study, $33(66 \%)$ were females. Majority of the subjects were 36-40 years old. A greater proportion of them $(52 \%)$ were married while $20 \%$ were single. A total of $26(52 \%)$ of the participants completed primary school, while up to $10(20 \%)$ completed secondary school (Table 1). Up to $98 \%$ of the subjects indicated that they were not trained in any vocation. Fifteen $(30 \%)$ admitted having sight impairment while 17 (34\%) admitted that they are physically challenged, while $14(28 \%)$ admitted they were not physically challenged. 
Table 1. Socio-demographic profile of beggars and destitute studied in Abakaliki metropolis, Ebonyi State Nigeria

\begin{tabular}{|c|c|c|}
\hline Parameter examined & Number & Percentage \\
\hline \multicolumn{3}{|l|}{ Gender } \\
\hline Male & 17 & 34 \\
\hline Female & 33 & 66 \\
\hline Total & 50 & \\
\hline \multicolumn{3}{|l|}{ Age } \\
\hline $20-25$ & 1 & 2 \\
\hline $26-30$ & 7 & 14 \\
\hline $31-35$ & 15 & 30 \\
\hline $36-40$ & 17 & 34 \\
\hline $41-45$ & 9 & 18 \\
\hline $46-50$ & 1 & 2 \\
\hline Total & 50 & \\
\hline \multicolumn{3}{|l|}{ Marital status } \\
\hline Married & 26 & 52 \\
\hline Single & 10 & 20 \\
\hline Separated & 5 & 10 \\
\hline Widowed & 9 & 18 \\
\hline Total & 50 & \\
\hline \multicolumn{3}{|c|}{ Highest educational qualification } \\
\hline None & 10 & 20 \\
\hline Primary 3 & 3 & 6 \\
\hline Primary 6 & 26 & 52 \\
\hline Senior Secondary 3 & 10 & 20 \\
\hline Diploma & 1 & 02 \\
\hline Total & 50 & \\
\hline \multicolumn{3}{|c|}{ Are you a trained worker? } \\
\hline Yes & 1 & 2 \\
\hline No & 49 & 98 \\
\hline Total & 50 & \\
\hline \multicolumn{3}{|c|}{$\begin{array}{l}\text { What type of impairment do you } \\
\text { have? }\end{array}$} \\
\hline Sight & 15 & 30 \\
\hline Speech & 4 & 8 \\
\hline Physically challenged & 17 & 34 \\
\hline None & 14 & 28 \\
\hline Total & 50 & \\
\hline
\end{tabular}

The outcome of the trainability assessment showed relatively high mean ratings (MNRs), ranging from 3.42 to 4.06 on a scale of 5 points (Table 2). The MNR for the degree at which participants look for a better way of doing things was 3.68. The MNRs for the extent to which they turn ideas into action; pursue tasks and issues until results are achieved; and solve problems creatively were
3.52, 3.60 and 3.64 respectively. The highest MNR of 4.06 was recorded for the extent to which the subjects are innovative. The MNR for the degree at which participants who are persistent and do not give up easily, are amenable to instructional details; are adaptive to change and receptive to the unexpected were 3.54, 3.52 and 3.86 respectively (Table 2). 
Table 2: Outcome of trainability questionnaire assessment of beggars and destitute in Abakaliki metropolis, Ebonyi State Nigeria

\begin{tabular}{|l|l|l|l|}
\hline Parameter assessed & Mean rating & $\begin{array}{l}\text { Media } \\
\text { rating }\end{array}$ & Range \\
\hline $\begin{array}{l}\text { 1. To what degree do you look for a } \\
\text { better way of doing things? }\end{array}$ & 3.68 & 4 & $2-5$ \\
\hline $\begin{array}{l}\text { 2. To what extent do you turn ideas } \\
\text { intoaction? }\end{array}$ & 3.52 & 3 & $1-5$ \\
\hline $\begin{array}{l}\text { 3. To what extent do you pursue tasks } \\
\text { and issues until results are achieved? }\end{array}$ & 3.60 & 4 & $2-5$ \\
\hline $\begin{array}{l}\text { 4. To what degree do you solve problems } \\
\text { creatively? }\end{array}$ & 3.64 & 4 & $1-5$ \\
\hline $\begin{array}{l}\text { 5. To what extent do you get on things } \\
\text { without been asked? }\end{array}$ & 3.64 & 4 & $1-5$ \\
\hline 6. To what extent are you innovative? & 4.06 & 4 & $2-5$ \\
\hline $\begin{array}{l}\text { 7. To what extent are you happy to take } \\
\text { the lead? }\end{array}$ & 3.42 & 3 & $1-5$ \\
\hline $\begin{array}{l}\text { 8. To what extent do you prefer full } \\
\text { information before making a decision? }\end{array}$ & 3.52 & 3 & $1-5$ \\
\hline $\begin{array}{l}\text { 9. To what degree are you persistent and } \\
\text { do not give up easily? }\end{array}$ & 3.54 & 3 & $1-5$ \\
\hline $\begin{array}{l}\text { 10. To what extent are you often the first } \\
\text { person to speak up? }\end{array}$ & 3.74 & 4 & $1-5$ \\
\hline $\begin{array}{l}\text { 11. To what degree do you like being told } \\
\text { what to do? }\end{array}$ & 3.52 & 4 & $1-5$ \\
\hline $\begin{array}{l}\text { 12. To what degree do you try to avoid } \\
\text { criticism? }\end{array}$ & 3.53 & 3 & $1-5$ \\
\hline $\begin{array}{l}\text { 13. To what extent are you easily } \\
\text { influenced by others' opinion? }\end{array}$ & 3.66 & 4 & $1-5$ \\
\hline $\begin{array}{l}\text { 14. To what extent do you prefer to do } \\
\text { one thing at a time? }\end{array}$ & 3.66 & 3 & $2-5$ \\
\hline $\begin{array}{l}\text { 15. To what degree do you look for } \\
\text { regular reassurance? }\end{array}$ & 3.86 & 4 & $2-5$ \\
\hline $\begin{array}{l}\text { 16. To what degree do you like change } \\
\text { and the unexpected? }\end{array}$ & 3.86 & 4 & $2-5$ \\
\hline $\begin{array}{l}\text { 17. To what degree do you need } \\
\text { encouragement to achieve goals? }\end{array}$ & 3.84 & 4 & \\
\hline
\end{tabular}

\section{Discussion}

The findings of this study clearly suggest that there is a very high potential for the vocational rehabilitation and reintegration of beggars and destitute persons into the society. This study was therefore very crucial as it provided baseline information that will guide the development of interventional effort for health improvement, rehabilitation and reintegrate beggars and destitute persons into the society. Evidence from previous studies have indicated that equipping beggars and destitute persons with vocational skills not only facilitated their contribution to economic development but also improved their health and wellbeing ${ }^{3,14-16}$. For instance, Ferguson ${ }^{14}$ noted that the use of social enterprise in USA including vocational training to provide homeless youths with marketable job skills and employment, impacted positively on their physical and mental health.

The result of this study revealed that more than half $(52 \%)$ of the destitute persons and beggars had first 
school leaving certificates while another $20 \%$ had senior secondary school certificates. Interestingly, one of the beggars admitted to possessing a diploma certificate. This suggests that there could be many beggars who possess secondary school and post-secondary school certificates. The implication of this is that many beggars and destitute persons possess basic education qualifications and could be trained in vocation skills that fit their academic backgrounds. In a recent report, it was noted that to eradicate poverty and extreme hunger, efforts should be geared towards discouraging professional begging by equipping both existing and prospective beggars with vocational skills for inclusive societal development ${ }^{3,12}$. Apart from poverty and extreme hunger, beggars and destitute persons are exposed to abuse that impact negatively on their health. In Tanzania, Namwata and $\mathrm{Mgabo}^{3}$ reported that beggars are constantly subjected to abusive languages from the public, harassments from municipal officials and police, harassment from fellow beggars, sun burn and cold during the nights, and sexual abuse.

The need to initiate intervention programmes that will equip beggars and destitute persons with vocational skills cannot be overstated. This is very imperative as more than $97 \%$ of the respondents in this study noted that they had no vocational skill. However, it must be understood that many persons engage in professional begging for different reasons: some see it as a lucrative business while others use it to disguise themselves and divert the attention of unsuspecting members of the society from the evil they intend to perpetrate ${ }^{6,7}$. Nweze and Okolie ${ }^{4}$, argued that regardless of the motive of individuals who engage in begging, equipping them with vocational skill is very needful to reducing the nuisance they constitute in the society and also the psychological trauma along with other health problems they receive from the society.

Nearly all the respondents admitted to having one form of impairment or the other. To many of them, the impairment was the reason they resorted to begging. However, it has been revealed that beggars and destitute persons impaired in one part of their body or the other can still use other parts of their bodies for productive ventures. Vasudha ${ }^{17}$ explained that despite certain physical challenges of beggars and destitute persons, they can be meaningfully engaged. He noted that a blind beggar after training, could be employed in the Ministry of Information where he/she could be used as a broadcaster or jingle singer and as well could be used in disseminating government information in public places. Through this type of meaningful engagement, these individuals can earn wages and seek better medical attention for their impairment.

The outcome of the trainability assessment in this study showed that many beggars and the destitute appear enthusiastic about being trained, focused on achieving goals, innovative, possess potentials to solve problems creatively and most importantly want to live healthy lives. With such abilities, beggars and the destitute when trained, can use their abilities in making meaningful contributing to economic development of the society and can live healthy lives. Beggars and the destitute can be equipped with vocational skills like shoe cobbling, soap making, movie artistry, music artistry, fine art, phone repairers etc. According to Osa-Edoh and Ayano ${ }^{18}$ one of the most important economic psychosocial needs of the beggars and the destitute interviewed in their study was learning a trade. Meaningful engagement in learned trade is among the critical predictors of good and healthy living and are germane to human existence and are necessary for beggars who were observed to have suffered abuse neglect and abandonment in the society ${ }^{4}$.

To give hope to beggars and destitute persons in Nigeria, successive Governments have initiated and implemented different programmes but such programmes seemedunsustainable. For instance, Ashiru19 reported that in 2014, the Federal Government of Nigeria inaugurated 19 members task force charged with getting beggars and destitute persons off the Federal Capital Territory streets. Such action led to the arrest and detention of many beggars, destitute persons and other individuals/groupsdescribed as environmental sanitation defaulters. Also in 2014, the Federal Government of Nigeria inaugurated 64 completed 'Almajiri' schools with the aim of sending beggars and destitute persons back to school. The same report states that three years after the inauguration, many of the Almajiri students abandoned the school and went back to street begging ${ }^{19}$. This clearly suggests that there is a need for development of public policy on vocational rehabilitation of beggars and the destitute. Adedibu and Jelili' ${ }^{6}$, observed that the policy implication of this is that different rehabilitation and control measures should be put in place for different categories of beggars, depending on the nature of predicament of each. For example, while poverty reduction strategies may be appropriate for most 
able-bodied, occasional beggars, functional and effective rehabilitation and healthcare services may be appropriate for disabled ones.

Such a policy is very important; and among the very critical issues the same policy must take into consideration is the implementation of strategies (such as vocational training) that will remove beggars and the destitute from the streets and public places. The policy must contain implementation strategies that will reverse the damage already done to the health including the conscience and psychology of the beggars and the destitute and restore their belief in the dignity of labour. Nwoye $e^{20}$ noted that through vocational guidance, individuals are given universal attention in understanding the meaning of work in human life; including survival trends in the career world and how to take care of their health.

The majority of these beggars and destitute are visibly idle and this further accentuates the adverse life events faced by them. For this, they need to be engaged in some meaningful ventures that will keep their minds active and productive. By so doing, major streets, motor parks and other public places could be rid of beggars and the destitute who can as well generate some income to support themselves and perhaps others.

\section{Conclusion}

Beggars and destitute persons, it must be noted, flock to cities every day hoping to find greener pastures. Thus, like every other person, they have no intention of leaving once they hit their gold mine. Even when they are arrested by some authorities and deported back to their communities of origin, they still manage to return. Therefore, in view of the foregoing, a public policy on their rehabilitation is an indispensable requirement to control the menace of begging and destitution in Nigeria and other LMICs with similar challenges.

\section{Acknowledgement}

This study was supported by the seed grant of the Tertiary Education Trust Fund (TETFund) Nigeria administered by the Ebonyi State University Abakaliki Nigeria. (Reference: EBSU/TETEFund/2015/038). Authors are grateful to all the individuals who participated in this study.

\section{Authors' contributions}

All authors participated in the design and development of the study. TN drafted the manuscript, all other authors made inputs to the final manuscript.

\section{Competing interests}

The authors declare no competing interest.

\section{References}

1. Bukoye RO. Case Study: Prevalence and consequences of street begging among Adults and Children in Nigeria, Suleja metropolis. Proc Soc Behav Sci. 2015; 171: 323-333. 2. Liman BM, Abubakar HS. Street Begging Reduction through Educating and Counseling Physical Challenged Persons in Sokoto State, Nigeria. Int J Res Engr Soc Sci. 2016; 6(12): 35-40.

3. Namwata BML, Mgabo MR. Consequences of begging and future aspirations of beggars to stop begging life in central Tanzania. Int Res J Hum Resources Soc Sci. 2014; 1(4): 176-187.

4. Nweze T, Okolie UC. Effective Vocational Guidance and Counselling Programmes: Creating Opportunities for Harnessing Potentials of Street Beggars. J Edu Prac. 2015; 6(26): 127-130

5. Kabir KS, Al-Helal A, Rahman M (2012) Measuring Socio-economic Conditions of Street Beggars at Dhaka City in Bangladesh: An Empirical Study. 2012. Available at: http://202.74.245.22:8080/xmlui/bitstream/ handle $/ 123456789 / 662 /$ Measuring $\% 20$ socio-economic $\% 20$ conditions $\% 20$ of $\% 20$ street $\% 20$ beggers $\% 20$ at $\% 20$ Dhaka $\% 20$ city $\% 20$ in $\% 20$ Bangladesh_Kabir $\% 20$ KS_15\%20Sep \%202012.pdf?sequence=1 Assessed February 18, 2017.

6. Adedibu AA, Jelili MO. Package for Controlling Street Begging and Rehabilitating Beggars and the Physically Challenged in Nigeria: Paper for Policy Consideration. Glob J Hum Soc Sci. 2011;11(1): 17-24

7. Namwata BML, Mgabo MR, Dimoso P (2012) Categories of Street Beggars and Factors Influencing Street Begging in Central Tanzania. Afr Stud Monogr. 2012; 33 (2): 133-143.

8. Demewozu W. Begging as a means of livelihood: conferring with the poor at the orthodox religious ceremonial days in Addis Ababa. Afri Stud Monogr. 2005; Suppl. 29:185-191.

9. Lal N. Criminalizing beggars instead of rehabilitating them. 2006. Available at: www.infochangeindia.org/humanrights Assessed February 18, 2017. 
10. Rubina I. Begging: A Menace in India. International journal of advanced research in management and social sciences. 2013. Available at: www.academia.edu/begging. Assessed February 18, 2017.

11. Vikash P. Short paragraph on Indian Beggars: Their problem and solutions. Discover the Importance of India. 2013. Available at: http://www.importantindia. com/9885/short-paragraph-on-indian-beggars-theirproblem-and-solutions/ Assessed February 18, 2017.

12. Johnson NA, Lavis JN. Procedures Manual for the 'Evaluating Knowledge Translation Platforms in Lowand Middle-Income Countries' Study. Hamilton, Canada: McMaster University Program in Policy Decision-Making. 2009.

13. Uneke CJ, Ezeoha AE, Uro-Chukwu H, Ezeonu CT, Ogbu O, Onwe F, Edoga C. Enhancing health policymakers' information literacy knowledge and skill for policymaking on control of infectious diseases of poverty in Nigeria. Online J Public Health Inform.2015; 7(2):e221

14. Ferguson KM. Merging the Fields of Mental Health and Social Enterprise: Lessons from Abroad and Cumulative Findings from Research with Homeless Youths. Community Ment Health J. 2012; 48(4):490-502.

15. Nwaopara U, Abasiubong F, Umoh O. Mental health care of homeless mentally ill Patients in Akwa Ibom state, Nigeria: Rehabilitation model, challenges and Strategies for improvement. J Int Res Med Pharm Sci. 2016; 10(2): 60-68.

16. Adedibu AA, Jelili MO. Package for Controlling Street Begging and Rehabilitating Beggars and the Physically Challenged in Nigeria: Paper for Policy Consideration. Global J Hum Soc Sci Res. 2011; 11(1):17-24.

17. Vasudha V. Government to train 3,000 to sing paeans to swachh Bharat, Bet Bachao, other campaigns in local trains. 2015. Available at: https://economictimes. indiatimes.com/news/politics-and-nation/governmentto-train-3000-beggars-to-sing-paeans-to-swachh-bharatbeti-bachao-other-campaigns-on-local-trains / articleshow/48336570.cms Assessed February 18, 2017.

18. Osa-Edoh G, Ayano S. The Prevalence of Street Begging in Nigeria and the Counselling Intervention Strategies. Rev European Stud. 2012; 4(4):77-83.

19. Ashiru T. Destitute, beggars, almajiris overrun Abuja. 2016. Available at: http://bulwarkintelligence.com/curated-osint/destitutes-beggars-almajiris-overrun-abuja/ Assessed February 18, 2017.

20. Nwoye A. Counselling Psychology for Africa. Jos: Fab Education Books. 1990. 